\title{
Stocking of Endangered Razorback Suckers in the Lower Colorado River Basin over Three Decades: 1974-2004
}

\author{
Jason D. Schooley* and Paul C. Marsh \\ School of Life Sciences, Arizona State University, Post Office Box 874501, Tempe, Arizona 85287-4501, USA
}

\begin{abstract}
The razorback sucker Xyrauchen texanus was historically widespread and abundant throughout the larger streams of the Colorado River basin, ranging from Sonora, Mexico, to Wyoming. The species was federally listed as endangered in 1991 because it has been extirpated from most of its range. Its decline is attributed to habitat loss and predation by nonnative fishes. Thirty years of federal and state effort have resulted in stocking millions of razorback suckers to the lower Colorado River basin, but only a few individuals have been recaptured because the young are rapidly consumed by introduced predators, resulting in insufficient recruitment to adulthood. Elderly, wild adults of this long-lived species are vanishing, and lower Colorado River basin recovery efforts now focus on replacement of these fish with repatriated (or reintroduced) adults. Stocking success and subsequent survival increases with size at release. When estimates of size-based, first-year survival rates were applied to individual batches of repatriated fish, we observed less than $1 \%$ overall first-year survival, and most fish stocked to date are thought to have been consumed soon after release. Overall, stocking has been unsuccessful, long-term survival is unknown, and no new populations have been established.
\end{abstract}

The razorback sucker Xyrauchen texanus, a large catostomid, was historically widespread and abundant throughout the larger streams of the Colorado River basin, ranging from Sonora, Mexico, to Wyoming (Minckley 1973; Minckley et al. 1991). Historical densities of the species are not well quantified, but before the introduction of nonnative fishes and the construction of dams on the Colorado River, razorback suckers were commonly utilized as human or animal food and fertilizer, and they even supported a commercial fishery (Minckley et al. 1991). The species was listed as endangered in 1991, following 10 years of failed reintroduction attempts (USFWS 1978, 1980, 1990, 1991). The few remaining wild populations are found in Lakes Mead and Mohave of the lower Colorado River basin and in portions of the Colorado, Duschene, Green, White, and lower Yampa rivers of the upper Colorado River basin (Modde et al. 1996; USFWS 1998, 2002; Marsh et al. 2003). Elsewhere the species is extirpated, except for scattered individuals, small aggregations, and reintroductions (Figure 1).

The razorback sucker's rarity accords with that of other big river fishes. Bonytail Gila elegans, humpback chub G. cypha, woundfin Plagopterus argentissimus, Colorado pikeminnow Ptychocheilus lucius, and desert pupfish Cyprinodon macularius are also federally listed as endangered. Flannelmouth sucker Catostomus latipinnis, bluehead sucker $C$. discobolus, roundtail

\footnotetext{
* Corresponding author: jschooley@asu.edu
}

Received May 31, 2005; accepted June 28, 2006 Published online February 1, 2007 chub G. robusta, and speckled dace Rhinichthys osculus have no federal protected status at this time, but they are extirpated from most of their historical ranges (Minckley et al. 2003). Additional native marine fishes (machete Elops affinis, spotted sleeper Eleotris picta, and striped mullet Mugil cephalus) entered the historical Colorado River from the Sea of Cortez, but dams and reduced river flows have since precluded their presence in all but the southernmost reaches.

The razorback sucker's decline is attributed to habitat loss and modification in concert with predation by introduced, nonnative fishes (Tyus and Saunders 2000; Clarkson et al. 2005; Marsh and Pacey 2005). Although adults spawn annually and produce offspring in the anthropogenically modified habitats (Marsh and Langhorst 1988; Holden et al. 2001a; Marsh et al. 2005), early life stages are rapidly consumed by introduced predators, curtailing recruitment to adulthood (Minckley and Deacon 1968; Miller 1972; Johnson and Rinne 1982; Medel-Ulmer 1983; Minckley 1983). Population declines continue in both the upper and lower basins (Holden et al. 2001a; Abate et al. 2002; Bestgen et al. 2002; Albrecht and Holden 2005; Arizona Game and Fish Department [AGFD], unpublished data). The decline of the abundant Lake Mohave population (Minckley et al. 1991; Dowling et al. 1996a; Turner et al., in press) was predicted by Minckley (1983) to occur soon after the year 2000; this decline has since been well documented (Minckley 1983; Minckley et al. 1991; Marsh et al. 2003; Marsh et al. 2005; Pacey and Marsh 2005), population estimates being fewer than 3,000 wild fish in 2001 


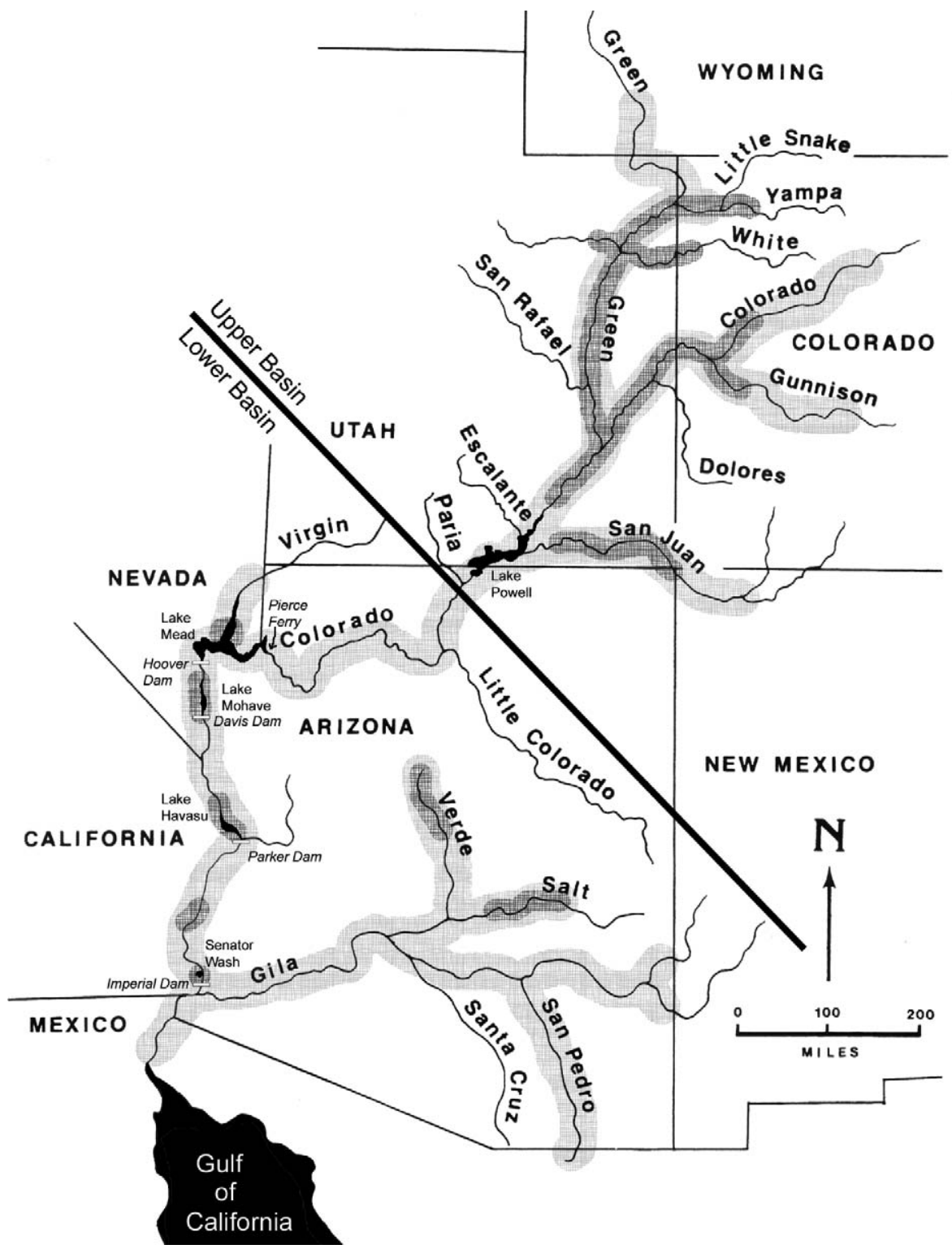

FIGURE 1.- Razorback sucker distribution, both historical (light shading) and present (dark shading); current reservoirs are shown in black. The historical distribution was adapted from Minckley et al. (1991), excluding the Salton Sea area. The present distribution was adapted from USFWS (2002) and Bestgen et al. (2002) and includes primary stocking locations in addition to areas of natural occupation.

(Marsh et al. 2003) and fewer than 1,500 repatriate fish in 2002 (Marsh et al. 2005). Elderly, wild adults of this long-lived species ( $>40$ years; McCarthy and Minckley 1987) are vanishing (Marsh et al. 2003; Marsh et al. 2005), and lower basin recovery efforts continue to focus on replacement of these fish with repatriated (or reintroduced) adults (USFWS 1998, 2002).
Early stockings were solely supported by artificial propagation, and initial technological development of these techniques began in 1974 when 40 wild adults were collected from Lake Mohave and became the first broodstock at Willow Beach National Fish Hatchery (Toney 1974). Similar transfers were made to Dexter National Fish Hatchery (now Dexter National Fish Hatchery and Technology Center) soon afterwards, and 
the progeny of paired matings were distributed to a suite of central Arizona rivers and streams. Since those pioneering efforts, accumulated knowledge has been used to modify razorback sucker repatriation protocols, resulting in two stocking approaches that differ both philosophically and practically.

The first stocking approach utilizes artificial propagation of hatchery broodstocks for repatriation to the main-stem Colorado River (including Lake Havasu) and other waters in Arizona, Utah, Colorado, and New Mexico. The second approach is embodied by the Lake Mohave repatriation program (Mueller 1995), in which only wild-born progeny are stocked, alleviating a possible bottleneck effect from utilizing a limited number of parents as broodstock in hatchery production (USFWS 2002). The high genetic diversity of this wild population (Dowling et al. 1996b) has been well preserved (Dowling et al. 2005), even though the wild population has been all but replaced by a repatriated one.

Under the terms of a biological opinion for lower Colorado River operations and maintenance (USFWS 1997), and working towards the goal of reestablishing self-sustaining populations, U.S. Bureau of Reclamation (USBR) was to stock 50,000 adults in Lake Mohave and 25,000 in Lake Havasu by 2000. These goals were quantitatively reached, but long-term survival of stocked fish has yet to be observed. The Colorado, Gila, Salt, and Verde rivers of the lower basin were designated as critical habitat for razorback suckers (USFWS 1991). Colorado River reaches deemed critical included (1) Pierce Ferry to Davis Dam, including Lakes Mead and Mohave to full pool elevation, and (2) Parker Dam to Imperial Dam, including the 100-year floodplain. The Razorback Sucker Recovery Plan (USFWS 1998) was amended and supplemented with recovery goals (USFWS 2002) and additionally by the Big-River Fishes Management Plan (also called the Lower Colorado River Management Plan; USFWS 2004). All three documents culminate in three management strategies: (1) augmentation (i.e., stocking of hatchery-reared fish), (2) the utilization of isolated habitats, and (3) taking advantage of unique opportunities (dam closures, establishing new habitats). Monitoring programs are ongoing throughout the basin, stocking success and survival being the primary gauge for the recovery efforts for the species.

We review here the razorback sucker stocking efforts for the lower Colorado River and connected bodies of water. Although the sources of information were diverse, errors and conflicting information were rare. This synthesis presents the most complete and accurate information currently available on this intensively managed species.

\section{Study Area}

The stocking and survival data we examined encompassed the lower Colorado River downstream from Lee's Ferry, Arizona (hereafter, lower river), plus the Gila, Salt, and Verde rivers and their tributaries in central Arizona (Figure 1). Stocking locations include floodplain lakes, reservoirs, backwaters, canals, isolated or closed habitats, streams, creeks, and main-stem rivers. There are eight dams on the lower main stem plus 11 more on its tributaries (USWPRS 1980); these have dramatically altered and in some cases eliminated the vast floodplains of the historical system (Mueller and Marsh 2002).

\section{Methods}

Stocking records for razorback sucker were compiled from agency stocking receipts, annual hatchery reports, and electronic hatchery records obtained from federal and state agencies, including USFWS, AGFD, California Department of Fish and Game (CDFG), USBR, and U.S. Bureau of Land Management (BLM). Additional information, such as site descriptions, was gathered from third-party sources (e.g., university personnel), stocking summaries, investigative reports (published literature and technical reports), interoffice memoranda, and personal communications.

Stocking records and other pertinent information (date, quantity, total length and weight statistics, tagging variables, stocking location, batch origin, and source of information) were entered into a Microsoft Access database. Original data were presented in various formats and often only partial information was available. Incomplete records were further investigated, completed if possible, and inconsistencies noted. Many stocking events were reflected by multiple sources, occasionally with differing totals or details. Stocking receipts generally were favored as more reliable compared with summary compilations or thirdparty literature.

Records were grouped by general destination: hatchery or grow-out facility, lower Colorado River below Parker Dam, central Arizona rivers (including the Gila, Salt, and Verde river watersheds), Lake Mead, Lake Mohave, Lake Havasu, or other locations (i.e., transfers to museums, refugia, aquaria, conservancies, universities, etc.). Fish transferred between hatcheries (e.g., federal to state) were not treated as repatriates until stocked into open waters. The category "other locations" generally involved transfers for novelty, investigative (sacrifice), or collection purposes and, 
therefore, with few exceptions, did not represent repatriates.

Individual stocking batches were analyzed by mean total length $(\overline{\mathrm{TL}})$. When no mean value was provided for a given stocking batch, one was derived (d $\overline{\mathrm{TL}}$ ) by one of the following three methods:

(1) The stocking record text was examined for clues and translated to dTL. For this method, the text had to include size data that could be easily translated to mean total length (e.g., "3-6-in fingerlings" would translate to $114 \mathrm{~mm}$ ).

(2) If no length data were available but weight data were, mean weight $(\overline{\mathrm{W}})$ was calculated and converted to $\mathrm{d} \overline{\mathrm{TL}}$ by inverse linear regressions of total length on weight (developed from log-transformed field measurements of paired weights and lengths; Kutner et al. 2005), namely, as

$$
\ln (\mathrm{d} \overline{\mathrm{TL}})=\text { intercept }+ \text { slope } \times \ln (\overline{\mathrm{W}}) .
$$

Fish were classified as small juvenile ( $\overline{\mathrm{W}}<10 \mathrm{~g})$, juvenile $(10 \leq \overline{\mathrm{W}} \leq 1,000 \mathrm{~g})$, and adult $(\overline{\mathrm{W}}>1,000$ $\mathrm{g}$ ), and the appropriate regression model was applied. (Conversions from weight to length were not used for larval fish.) Parameter estimates and $95 \%$ confidence intervals (CIs) are shown in Table 1. For the adults, growth was first determined by gender. Using a weight-length correlation to estimate $\overline{\mathrm{TL}}$ for an adultstage stocking batch requires the assumption of a $1: 1$ male : female ratio. Therefore, $\mathrm{d} \overline{\mathrm{TL}}$ was calculated for males and females individually and a mean derived from these two values.

(3) Minimum TL was used in the place of TL. The decision to use the minimum TL rather than the maximum or an average based on the minimum and maximum was based on several factors. First, the minimum TL was often provided instead of the mean. Second, according to hatchery personnel, an average derived from the minimum and maximum values would not be an adequate substitute for the actual mean because of TL frequency distributions and

TABLE 1.-Parameter estimates and confidence intervals (CIs) for inverse regressions of log-transformed mean total length on log-transformed mean weight for razorback sucker stocking batches, lower Colorado River basin.

\begin{tabular}{|c|c|c|c|c|}
\hline \multirow[b]{2}{*}{ Category } & \multicolumn{2}{|c|}{ Intercept } & \multicolumn{2}{|c|}{ Slope } \\
\hline & Estimate & $95 \% \mathrm{CI}$ & Estimate & $95 \% \mathrm{CI}$ \\
\hline Small juveniles & 3.817 & $3.804-3.831$ & 0.289 & $0.266-0.312$ \\
\hline Juveniles & 3.862 & $3.843-3.882$ & 0.328 & $0.324-0.331$ \\
\hline Males & 3.998 & $3.937-4.059$ & 0.308 & $0.300-0.317$ \\
\hline Females & 3.978 & $3.906-4.050$ & 0.312 & $0.302-0.322$ \\
\hline
\end{tabular}

varying growth rates within batches (i.e., a few large fish in a batch of smaller fish).

The analysis applied size-based survival estimates to each individual batch of stocked fish. First-year survival was calculated from estimates of first-year survival based on TL at release (as in Marsh et al. 2005). The following formula was applied:

$$
S=\frac{\exp \left(\frac{\mathrm{TL}}{1,000} \times \beta\right)+\mathrm{INT}}{1+\exp \left(\frac{\mathrm{TL}}{1,000} \times \beta\right)+\mathrm{INT}},
$$

where $S=$ survival rate, $\beta=22.782459$, INT $=$ -9.0170896 , and TL (here, d $\overline{T L}$ ) is in millimeters. The formula is derived from mark-recapture data for razorback suckers repatriated to Lake Mohave, Arizona and Nevada, 1992-2002. Figure 2 graphically depicts this size-based first year survival relationship.

We attempted to estimate the portion of these 14.6 million first-year fish that are alive today. We applied the Lake Mohave survival model to stocking locations elsewhere because limited capture data precluded similar formulations for each location. Lower river surveys during 2003-2004 resulted in few razorback sucker captures and only one recapture (Schooley et al. 2004), and similar results were reported for the Verde and Salt rivers during 1991-2004 (Hyatt 2004). Both examples indicate low poststocking survival, which is consistent with the Lake Mohave model. There are no other survival models for razorback suckers, and although survival may be site-specific, we believe the Lake Mohave model provided suitable estimates for survival in other lower basin populations.

\section{Results}

Records indicate that a total 14.6 million razorback suckers were repatriated in 544 separate batches distributed to nearly 200 individual sites within the

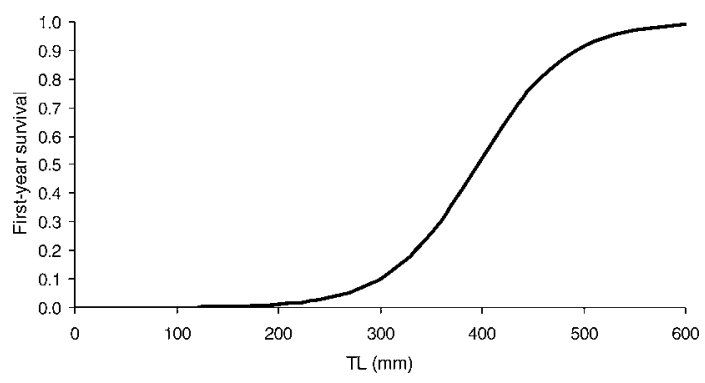

FIGURE 2.-First-year survival curve as a function of total length (TL) at release for repatriated razorback suckers that were later recaptured as adults during annual March censuses in Lake Mohave, Arizona-Nevada, 1992-2002 (reproduced from Marsh et al. 2005). 
lower Colorado River and tributaries (Table 2); the number of stocking sites is approximate because of equivocal site descriptions and the use of ambiguous synonyms. Although the initial broodstock was collected in 1974, available records indicate that the first repatriation consisted of 354 juveniles returned to Lake Mohave in 1978 (Toney 1974). Razorback suckers have been distributed in the following quantities: 146 to Lake Mead, 124,942 to Lake Mohave, 514,098 to Lake Havasu, 2.5 million to the lower river below Parker Dam, and 11.4 million to central Arizona rivers and streams (including the Verde River [837,347], Salt River [9.4 million], and Gila River [1 million]).

Records corresponding to $1.5 \%$ of all repatriated fish lacked sufficient size details and were therefore excluded from analysis. These records, generally from summaries or third-party sources, were not reflected in stocking receipts or hatchery reports.

Inverse linear regressions for razorback sucker total length and weight resulted in high coefficients of determination and similar relationships across size and gender categories, including small juveniles $(N=47$; $\left.R^{2}=0.94\right)$, juveniles $\left(N=2,138 ; R^{2}=0.93\right)$, adult males $\left(N=515 ; R^{2}=0.90\right)$, and adult females $(N=$ $\left.278 ; R^{2}=0.93\right)$.

Among stocking records for which size data were provided or inferred, $85 \%$ were larvae $(<27 \mathrm{~mm} \mathrm{TL}$; Snyder 1981). Most fish (96\%) were repatriated at an average annual rate of 2 million fish during the period 1982-1988, before listing as an endangered species. For the 13 years (1992-2004) since listing, an average of 26,227 fish were stocked annually (range, 5,77579,313).

\section{Discussion}

First-year survival estimates (Table 2) suggest that 39,149 fish survived the first year after release, a $0.27 \%$ survival rate. Because the spatial and temporal variations in first-year survival rates (Table 2) are based solely on the mean size at release for individual batches, they may be misleading, however. For example, it might seem that the Lake Mead stockings were the most successful based on the estimated $65 \%$

TABLE 2.- Razorback suckers stocked annually into the lower Colorado River basin and, in parentheses, the estimated number of first-year survivors as formulated from derived mean total length (dTL).This table excludes stocking batches for which size data were insufficient for survival rate estimation; those batches (3,274 fish in Lake Mohave, 6,975 fish in Lake Havasu, 24,020 fish in the lower river, and 196,275 fish in central Arizona waters) total 14,564,677 fish stocked into the lower Colorado River basin.

\begin{tabular}{|c|c|c|c|c|c|c|c|c|}
\hline \multirow{2}{*}{$\begin{array}{c}\text { Year, d } \overline{\mathrm{TL}} \text {, } \\
\text { and } \\
\text { survival }\end{array}$} & \multicolumn{8}{|c|}{ Stocking site } \\
\hline & $\begin{array}{l}\text { Lake } \\
\text { Mead }\end{array}$ & $\begin{array}{c}\text { Lake } \\
\text { Mohave }\end{array}$ & $\begin{array}{c}\text { Lake } \\
\text { Havasu }\end{array}$ & $\begin{array}{l}\text { Lower } \\
\text { River }\end{array}$ & $\begin{array}{c}\text { Central } \\
\text { Arizona waters }\end{array}$ & All sites & $\begin{array}{l}\mathrm{d} \overline{\mathrm{TL}} \\
(\mathrm{mm})\end{array}$ & $\begin{array}{c}\text { Survival } \\
(\%)\end{array}$ \\
\hline 1980 & & & & 79 (16) & & 79 (16) & 334 & 20.25 \\
\hline 1981 & & & & & $7,000(6)$ & $7,000(6)$ & 81 & 0.09 \\
\hline 1982 & & & & & $612,627(143)$ & $612,627(143)$ & 18 & 0.02 \\
\hline 1983 & & & & $457(0)$ & $2,664,296(590)$ & $2,664,753(590)$ & 16 & 0.02 \\
\hline 1984 & & & & & $3,183,235(705)$ & $3,183,235(705)$ & 16 & 0.02 \\
\hline 1985 & & & & $57(4)$ & $3,026,687(677)$ & $3,026,744(681)$ & 18 & 0.02 \\
\hline 1986 & & & $466,923(71)$ & $1,045,271(412)$ & $718,531(362)$ & $2,230,725(845)$ & 30 & 0.04 \\
\hline 1987 & & & & $1,276,367$ (278) & $334,018(308)$ & $1,610,385(586)$ & 28 & 0.04 \\
\hline 1988 & & & & $1,700(13)$ & $558,532(465)$ & $560,232(478)$ & 30 & 0.09 \\
\hline 1989 & & & & $1,375(145)$ & $79,680(679)$ & $81,055(824)$ & 103 & 1.02 \\
\hline 1990 & & & & $3,039(560)$ & $7,228(103)$ & $10,267(663)$ & 242 & 6.46 \\
\hline 1991 & & & & & $3,968(72)$ & $3,968(72)$ & 197 & 1.81 \\
\hline 1992 & & $10,899(42)$ & & & $207(40)$ & $11,106(82)$ & 84 & 0.74 \\
\hline 1993 & & $1,358(16)$ & $1,949(810)$ & $14,006(16)$ & $1,120(181)$ & $18,433(1,023)$ & 141 & 5.55 \\
\hline 1994 & & $2,195(63)$ & $6(2)$ & $81(6)$ & $3,493(1,448)$ & $5,775(1,519)$ & 320 & 26.3 \\
\hline 1995 & $40(37)$ & $1,501(181)$ & $9,888(12)$ & $13,514(92)$ & $3,156(288)$ & $28,099(610)$ & 129 & 2.17 \\
\hline 1996 & & 3,094 (297) & $91(12)$ & $70,165(84)$ & $5,963(741)$ & $79,313(1,134)$ & 81 & 1.43 \\
\hline 1997 & $6(6)$ & $7,317(471)$ & $986(249)$ & $2,000(53)$ & $1,641(484)$ & $11,950(1,263)$ & 283 & 10.57 \\
\hline 1998 & $11(11)$ & 7,667 (788) & $9,332(2,149)$ & $62(50)$ & $2,391(293)$ & $19,463(3,291)$ & 321 & 16.91 \\
\hline 1999 & $39(0)$ & $20,166(1,358)$ & $6,358(1,320)$ & $2,421(268)$ & $2,000(454)$ & $30,984(3,400)$ & 294 & 10.97 \\
\hline 2000 & & 7,215 (993) & $4,634(1,000)$ & $4,380(337)$ & $2,131(326)$ & $18,360(2,656)$ & 310 & 14.47 \\
\hline 2001 & $9(9)$ & $15,392(2,221)$ & $6,784(1,349)$ & $4,425(558)$ & $1,574(206)$ & $28,184(4,343)$ & 318 & 15.41 \\
\hline 2002 & $23(14)$ & $11,747(1,704)$ & $30(21)$ & $15,548(1,144)$ & $2,022(412)$ & $29,370(3,295)$ & 299 & 11.22 \\
\hline 2003 & $12(12)$ & $19,638(3,630)$ & $142(23)$ & $14,070(1,135)$ & $378(69)$ & $34,240(4,869)$ & 313 & 14.22 \\
\hline 2004 & $6(6)$ & $13,479(3,484)$ & & $9,869(1,692)$ & $2,325(873)$ & $25,679(6,055)$ & 342 & 23.58 \\
\hline All years & $146(95)$ & $121,668(15,248)$ & $507,123(7,018)$ & $2,478,886(6,863)$ & $11,224,203(9,925)$ & $14,332,026(39,149)$ & & \\
\hline $\mathrm{d} \overline{\mathrm{TL}}$ & 444 & 286 & 32 & 27 & 23 & 26 & & \\
\hline Survival (\%) & 65.07 & 12.53 & 1.38 & 0.28 & 0.09 & 0.27 & & \\
\hline
\end{tabular}


survival rate at that location, but this rate is attributable to the large size of the razorback suckers stocked into Lake Mead $(\mathrm{d} \overline{\mathrm{TL}}=444 \mathrm{~mm})$. On the other hand, the stockings into central Arizona waters might seem to be the least successful based on the estimated survival rate of $0.09 \%$. This, however, is simply the result of the small size of the fish stocked into those waters $(\mathrm{d} \overline{\mathrm{TL}}=$ $23 \mathrm{~mm})$. We are therefore not implying that any stocking locations are more suitable than others.

Though most fish were stocked during 1982-1988, the estimated survival of pre-1997 stockings was negligible $(0.07 \%)$. Conversely, three-fourths of the overall survivors were stocked during 1997-2004 (Figure 3); the estimated post-1996 survival rate was $14.72 \%$ (range, 10.57-23.58\%). The Arizona State University (ASU) native fish mark-recapture database indicates that less than $0.02 \%$ of the razorback suckers stocked into the lower basin have been recaptured to date (C. Pacey, ASU, personal communication), and nearly one-fourth of these recaptures occurred a short time after stocking.

Considering the long stocking history and number of fish stocked, the razorback sucker is arguably further from recovery now than when stocking began in 1974. Minckley et al. (2003) indicate that the wild population of razorback suckers in Lake Mohave alone was near 73,000 during 1980-1993. This estimate probably eclipses the total population of razorback suckers persisting in the wild today. The flagship population in Lake Mohave has since dwindled to fewer than 3,000 wild fish in 2001 (Marsh et al. 2003) and fewer than 500 fish in 2006 (unpublished data). Quantitative recovery goals require establishment of multiple populations, each of at least 5,800 adult fish, before down-listing can occur (USFWS 2002), a result that seems unlikely anytime soon in view of currently available information.

In retrospect, it makes little sense to produce and stock millions of larvae ( $85 \%$ of all repatriates to date) and expect them to have a better chance of surviving than the wild-produced variety. Nonetheless, it has taken more than 30 years for the lower basin stocking program to evolve in a way that notably increases survival to adulthood (i.e., repatriates now spend all of their early life stages in protected environments). Strict adherence to this protocol is likely to produce a measurable increase in repatriate captures near recent stocking locations, after which time survival rates for point locations may be estimated.

Although reintroduction of the razorback sucker to historical habitat is presently the prevailing species conservation strategy, the ultimate goal still is the reestablishment of self-sustaining populations (USFWS 2002). Nonnative predator and native prey interaction indicates that this goal is not attainable with simple replacement. Interactions between native and nonnative fishes in the Southwest have been thoroughly studied (Minckley and Deacon 1968; Minckley 1973; Meffe 1985; Minckley and Jensen 1985; Minckley and Deacon 1991; Blinn et al. 1993; Douglas et al. 1994; Pacey and Marsh 1998; Bryan et al. 2000; Tyus and Saunders III 2000; Mueller and Marsh 2002; Marsh and Pacey 2005; Mueller 2005). Successful natural recruitment has been demonstrated repeatedly in habitats absent of nonnative predators (Marsh and Pacey 2005), and also in the presence of native omnivores such as bonytails (Mueller et al. 2004). Minimal natural recruitment has been observed in Lake Mead, but it is the exception to the norm (Abate et al. 2002; Albrecht and Holden 2005). Considering that

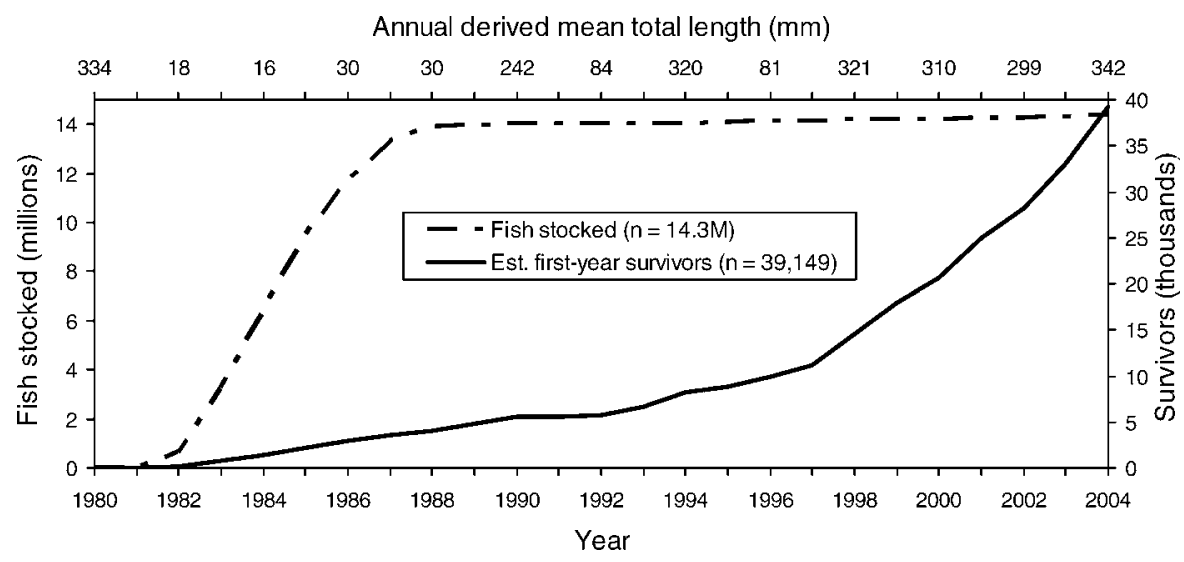

FIGURE 3.-Cumulative numbers of razorback suckers stocked into the lower Colorado River basin from 1980 to 2004 and estimated numbers of first-year survivors formulated from size at release. Estimates of annual derived mean total lengths appear at the top of the figure. 
poor survival of repatriated fish probably is indicative of the losing battle between imperiled native fishes and introduced predators, the future management of natives undoubtedly lies in the creation of segregated habitats (Clarkson et al. 2005). Such habitats are both presently available (but underutilized) and easily created and managed. A plan for the design, creation, and management of predator-free habitats for native fish is presented by Minckley et al. (2003) and reiterated in the Big-River Fishes Management Plan (USFWS 2004), but the mechanisms have not been achievable due to inter- and intra-agency conflicts regarding the management and disposition of nonnative sport fishes and native species (see also Clarkson et al. 2005). However, implementation of the Multi-Species Conservation Plan, a 50-year, \$626-million conservation initiative enacted in April 2005, will presumably alleviate many of these roadblocks.

The razorback sucker stocking program as a whole has shown limited success. Early stocking efforts mostly were mass releases of young fish to replenish disappearing populations, but they were in vain because fish disappeared soon after stocking and long-term survival was negligible. Statistical analyses show a logistic relationship between size at release and subsequent-year survival, where bigger is better in respect to release size (Marsh et al. 2005). Therefore, lower basin repatriates presently are held in nonnativefree environments until they reach at least $300 \mathrm{~mm}$ TL. This takes at least a year to attain, and only about $10 \%$ survive their first year in the wild. Had the earlier incantations of the razorback sucker repatriation program been based on today's knowledge of sizebased survival, this review would tell a completely different story. If all repatriates had been released at $350 \mathrm{~mm}$ TL, we would estimate more than a 100-fold increase in survivors today.

Stocking programs have become the cornerstone for recovery of western native fishes (USFWS 2004), but the implementation and outcomes have been variable. Notable success was realized for cui-ui Chasmistes cujus in Pyramid Lake (Scoppettone et al. 1986). The same could be said for Colorado pikeminnow in the San Juan River (Brooks et al. 2000), but this program was accompanied by aggressive nonnative fish control. Stocked bonytails have yet to establish new populations anywhere in the Colorado River, and repatriation programs for Colorado pikeminnow and razorback suckers in central Arizona have similarly failed (Hyatt 2004). Further, stocking programs for smaller fishes, such as woundfin (Holden et al. 2001b), Gila topminnow Poeciliopsis occidentalis (Voeltz and Bettaso 2004), have not met expectations (Minckley and Brooks 1985; DFT 2003, 2004). In stark contrast, three-fourths of more than 100 nonnative fish species released into the lower Colorado River basin have established populations, or still are actively stocked in the region.

Short of the eradication of or strict segregation from nonnative predators and the decommissioning of dams to restore historical floodplain habitats and floods, continued human management of razorback suckers is the only means of perpetuating this species. A proactive, continued increase in minimum release size is cost-effective for this species (C. Figiel, personal communication) and would have a dramatic effect on poststocking survival to adulthood.

\section{Acknowledgments}

The authors thank members of the Native Fish Laboratory at ASU (Tom Dowling, Brian Kesner, James Lee, Carol Pacey, and Darren Thornbrugh) for their assistance with data compilation and manuscript review; AGFD (Frank Agyagos, Brad Jacobson, Anne Kretschmann, Laura Leslie, and Roger Sorensen), CDFG (Chris Hayes and Joe Millosovich), USBR (Tom Burke and Ty Wolters), and USFWS (Chester Figiel, Chuck Minckley, and Manuel Ulibarri) for their assistance with data assembly; and Gordon Mueller (USGS) and anonymous reviewers for their comments on this document.

\section{References}

Abate, P. D., T. Welker, and P. B. Holden. 2002. Razorback sucker studies on Lake Mead, Nevada and Arizona. Department of Resources, Las Vegas, Nevada, and BioWest, Inc., Logan, Utah.

Albrecht, B., and P. B. Holden. 2005. Razorback sucker studies on Lake Mead, Nevada. Annual report to the Southern Nevada Water Authority. Bio-West, Inc., Logan, Utah.

Bestgen, K. R., G. B. Haines, R. Brunson, T. Chart, M. Trammell, R. T. Muth, G. Birchell, K. Christopherson, and J. M. Bundy. 2002. Status of wild razorback sucker in the Green River basin, Utah and Colorado, determined from basinwide monitoring and other sampling programs. Larval Fish Laboratory, Department of Fishery and Wildlife Biology, Colorado State University, Fort Collins.

Blinn, D. W., C. Runck, and D. A. Clark. 1993. Effects of rainbow trout predation on little Colorado spinedace. Transactions of the American Fisheries Society 122:139143.

Brooks, J. E., M. J. Buntjer, and J. R. Smith. 2000. Nonnative species interactions: management implications to aid in recovery of the Colorado pikeminnow Ptychocheilus lucius and razorback sucker Xyrauchen texanus in the San Juan River. U.S. Fish and Wildlife Service, CO-NMUT, Albuquerque, New Mexico.

Bryan, S. D., A. T. Robinson, and M. J. Fry. 2000. Nativenonnative fish interactions in the lower Salt and Verde 
rivers. Arizona Game and Fish Department, Final report to the U.S. Bureau of Reclamation, Cooperative Agreement 98-FG-32-0240, Phoenix.

Clarkson, R. W., P. C. Marsh, S. E. Stefferud, and J. A. Stefferud. 2005. Conflicts between native fish and nonnative sport fish management in the southwestern United States. Fisheries 30(9):20-27.

DFT (Desert Fishes Team). 2003. Status of federal- and statelisted warmwater fishes of the Gila River basin, with recommendations for management. Desert Fishes Team Report 1. Available: www.nativefishlab.net/ Desert_Fishes_Team.htm. (May 2006).

DFT (Desert Fishes Team). 2004. Status of unlisted native fishes of the Gila River basin, with recommendations for management. Desert Fishes Team Report 2. Available: www.nativefishlab.net/Desert_Fishes_Team.htm. (May 2006).

Douglas, M. E., P. C. Marsh, and W. L. Minckley. 1994. Indigenous fishes of western North America and the hypothesis of competitive displacement: Meda fulgida (Cyprinidae) as a case study. Copeia 1994:9-19.

Dowling, T. E., W. L. Minckley, and P. C. Marsh. 1996a. Mitochondrial DNA diversity within and among populations of razorback sucker (Xyrauchen texanus) as determined by restriction endonuclease analysis. Copeia 1996:542-550.

Dowling, T. E., W. L. Minckley, P. C. Marsh, and E. S. Goldstein. 1996b. Mitochondrial DNA variability in the endangered razorback sucker (Xyrauchen texanus): analysis of hatchery stocks and implications for captive propagation. Conservation Biology 10:120-127.

Dowling, T. E., P. C. Marsh, A. T. Kelsen, and C. A. Tibbets. 2005. Genetic monitoring of wild and repatriated populations of endangered razorback sucker (Xyrauchen texanus, Catostomidae, Teleostei) in Lake Mohave, Arizona-Nevada. Molecular Ecology 14:123-135.

Holden, P. B., P. D. Abate, and T. L. Welker. 2001a. Razorback sucker studies on Lake Mead, Nevada. Annual Report to the Southern Nevada Water Authority. Bio-West, Inc., Logan, Utah.

Holden, P. B., M. E. Golden, and S. J. Zucker. 2001b. An evaluation of changes in woundfin (Plagopterus argentissimus) populations in the Virgin River, Utah, Arizona, and Nevada, 1976-1999. Bio-West, Inc., Logan, Utah.

Hyatt, M. W. 2004. Assessment of Colorado pikeminnow and razorback sucker reintroduction program in the Gila River basin. Arizona Game and Fish Department, Final Report Submitted to the U.S. Fish and Wildlife Service, Region 2, Albuquerque, New Mexico.

Johnson, J. E., and J. N. Rinne. 1982. The Endangered Species Act and southwest fishes. Fisheries 7(4):3-8.

Kutner, M. H., C. J. Nachtscheim, J. Neter, and W. Li. 2005. Applied linear statistical models, 5th edition. McGrawHill/Irwin, New York.

Marsh, P. C., B. R. Kesner, and C. A. Pacey. 2005. Repatriation as a management strategy to conserve a critically imperiled fish species. North American Journal of Fisheries Management 25:547-556.

Marsh, P. C., and D. R. Langhorst. 1988. Feeding and fate of wild larval razorback sucker. Environmental Biology of Fishes 21:59-67.

Marsh, P. C., and C. A. Pacey. 2005. Immiscibility of native and nonnative fishes. Pages 59-63 in M. J. Brouder, C. L. Springer, and S. C. Leon, editors. Proceedings of two symposia: Restoring Native Fish to the Lower Colorado River-Interactions of Native and Nonnative fishes and Restoring Natural Function within a Modified Riverine Environment-The Lower Colorado River. U.S. Fish and Wildlife Service, Albuquerque, New Mexico.

Marsh, P. C., C. A. Pacey, and B. R. Kesner. 2003. Decline of the razorback sucker in Lake Mohave, Colorado River, Arizona and Nevada. Transactions of the American Fisheries Society 132:1251-1256.

McCarthy, M. S., and W. L. Minckley. 1987. Age estimation for razorback sucker (Pisces: Catostomidae) from Lake Mohave, Arizona and Nevada. Journal of the ArizonaNevada Academy of Sciences 21:87-97.

Medel-Ulmer, L. 1983. Movement and reproduction of the razorback sucker (Xyrauchen texanus) inhabiting Senator Wash Reservoir, Imperial County, California. Proceedings of Desert Fishes Council 12:106.

Meffe, G. K. 1985. Predation and species replacement in American Southwestern fishes: a case study. Southwestern Naturalist 30:173-187.

Miller, R. R. 1972. Threatened freshwater fishes of the United States. Transactions of the American Fisheries Society 101:239-252.

Minckley, W. L. 1973. Fishes of Arizona. Arizona Game and Fish Department, Phoenix.

Minckley, W. L. 1983. Status of the razorback sucker, Xyrauchen texanus (Abbott), in the lower Colorado River basin. Southwestern Naturalist 28:165-187.

Minckley, W. L., and J. E. Brooks. 1985. Transplantations of native Arizona fishes: records through 1980. Journal of the Arizona-Nevada Academy of Science 20:73-89.

Minckley, W. L., and J. E. Deacon. 1968. Southwestern fishes and the enigma of "endangered species." Science 159:1424-1432.

Minckley, W. L., and J. E. Deacon. 1991. Battle against extinction: native fish management in the American West. University of Arizona Press, Tucson.

Minckley, W. L., and B. L. Jensen. 1985. Replacement of Sonoran topminnow by Pecos Gambusia under hatchery conditions. Southwestern Naturalist 30:465-466.

Minckley, W. L., P. C. Marsh, J. E. Brooks, J. E. Johnson, and B. L. Jensen. 1991. Management toward recovery of the razorback sucker. Pages 303-357 in W. L. Minckley and J. E. Deacon, editors. Battle against extinction: native fish management in the American West. University of Arizona Press, Tucson.

Minckley, W. L., P. C. Marsh, J. E. Deacon, T. E. Dowling, P. W. Hedrick, W. J. Matthews, and G. Mueller. 2003. A conservation plan for native fishes of the lower Colorado River. Bioscience 53:219-234.

Modde, T., K. P. Burnham, and E. J. Wick. 1996. Population status of the razorback sucker in the middle Green River (USA). Conservation Biology 10:110-119.

Mueller, G. A. 1995. A program for maintaining the razorback sucker in Lake Mohave. Pages 127-135 in H. L. Schramm, Jr., and R. G. Piper, editors. Uses and effects of cultured fishes in aquatic ecosystems. American Fisheries Society, Symposium 15, Bethesda, Maryland.

Mueller, G. A. 2005. Predatory fish removal and native fish 
recovery in the Colorado River main stem: what have we learned? Fisheries 30(9):10-19.

Mueller, G. A., and P. C. Marsh. 2002. Lost: a desert river and its native fishes-a historical perspective of the Lower Colorado River. U.S. Geological Survey, Information and Technology Report USGS/BRD/ITR-2002-0010, U.S. Government Printing Office, Denver.

Mueller, G. A., J. Carpenter, and P. C. Marsh. 2004. Cibola High Levee Pond Annual Report 2004. U.S. Geological Survey, Fort Collins Science Center, Open-File Report 2005-1075, Fort Collins, Colorado.

Pacey, C. A., and P. C. Marsh. 1998. Resource use by native and nonnative fishes of the lower Colorado River: literature review, summary, and assessment of relative roles of biotic and abiotic factors in management of an imperiled indigenous ichthyofauna. Final report to the U.S. Bureau of Reclamation, Lower Colorado Region, Contract 7-MT-30-R0012. Arizona State University, Tempe.

Pacey, C. A., and P. C. Marsh. 2005. A decade of managed and natural population change for razorback sucker in Lake Mohave, Colorado River, Arizona and Nevada. Pages 104-108 in M. J. Brouder, C. L. Springer, and S. C. Leon, editors. Proceedings of two symposia: Restoring Native Fish to the Lower Colorado River-Interactions of Native and Nonnative Fishes; and Restoring Natural Function within a Modified Riverine Environment-The Lower Colorado River. U.S. Fish and Wildlife Service, Albuquerque, New Mexico.

Schooley, J. D., D. J. Thornbrugh, and P. C. Marsh. 2004. Survival of razorback sucker stocked into the lower Colorado River, Final project report, October 2002September 2004. U.S. Bureau of Reclamation, Agreement Number 02FG300043, Boulder City, Nevada.

Scoppettone, G. G., M. Coleman, and G. A. Wedemeyer. 1986. Life history and status of the endangered cui-ui of Pyramid Lake, Nevada. Fish and Wildlife Research 1:1-23.

Snyder, D. E. 1981. Contributions to a guide to the cypriniform fish larvae of the upper Colorado River system in Colorado. U.S. Bureau of Land Management, Biological Sciences Series 3, Denver, Colorado.

Toney, D. P. 1974. Observations on the propagation and rearing of two endangered fish species in a hatchery environment. Proceedings of Western Association of State Game and Fish Commissioners 54:252-259.

Turner, T. F., T. E. Dowling, P. C. Marsh, B. R. Kesner, and A. T. Kelsen. In press. Effective size, census size, and genetic monitoring of the endangered razorback sucker, Xyrauchen texanus. Conservation Genetics.
Tyus, H. M., and J. F. Saunders III. 2000. Nonnative fish control and endangered fish recovery: lessons from the Colorado River. Fisheries 25(9):17-24.

USFWS (U.S. Fish and Wildlife Service). 1978. Proposed endangered status for the bonytail chub and threatened status for the razorback sucker. Federal Register 43:79(24 April 1978): 17375-17377.

USFWS (U.S. Fish and Wildlife Service). 1980. Notice of withdrawal of an expired proposal for listing of the razorback sucker. Federal Register 45:103(27 May 1980):35410.

USFWS (U.S. Fish and Wildlife Service). 1990. Endangered and threatened wildlife and plants: proposal to determine the razorback sucker (Xyrauchen texanus) to be an endangered species. Federal Register 55:99(22 May 1990):21154-21161.

USFWS (U.S. Fish and Wildlife Service). 1991. Endangered and threatened wildlife and plants: the razorback sucker (Xyrauchen texanus) determined to be an endangered species. Federal Register 56:205(23 October 1991):54957-54967.

USFWS (U.S. Fish and Wildlife Service). 1997. Final biological and conference opinion on lower Colorado River operations and maintenance: Lake Mead to southerly international boundary. U.S. Fish and Wildlife Service, Albuquerque, New Mexico.

USFWS (U.S. Fish and Wildlife Service). 1998. Razorback sucker (Xyrauchen texanus) recovery plan. U.S. Fish and Wildlife Service, Denver.

USFWS (U.S. Fish and Wildlife Service). 2002. Razorback sucker (Xyrauchen texanus) recovery goals: amendment and supplement to the razorback sucker recovery plan. U.S. Fish and Wildlife Service, Denver.

USFWS (U.S. Fish and Wildlife Service). 2004. Management plan for the big-river fishes of the lower Colorado River basin: amendment and supplement to the bonytail, humpback chub, Colorado pikeminnow, and razorback sucker recovery plans. U.S. Fish and Wildlife Service, Albuquerque, New Mexico.

USWPRS (U.S. Water and Power Resources Service). 1980. Statistical compilation: storage dams, dikes, reservoirs, and diversion dams on water and power resources service projects. USWPRS, Denver.

Voeltz, J. B., and R. H. Bettaso. 2004. Gila topminnow and desert pupfish monitoring and management activities on BLM lands in Arizona, October 2002 through October 2003. Arizona Game and Fish Department, Phoenix. 